\title{
TRANSNATIONAL BANKS' INFLUENCE ON THE DEVELOPMENT OF THE ECONOMY AND THE FINANCIAL SECTOR OF DEVELOPING COUNTRIES (ON THE EXAMPLE OF POLAND, BRAZIL, TURKEY)
}

The main purpose of transnational banks is to mobilize and redistribute funds in such a way as to maximize profits. The foreign economic activity of TNB is a generating factor for the expansion and development of globalization processes, the economic ties of most countries in the world. The increasing importance of TNBs in the world economy is explained by the consolidation of banking and industrial capital, which is an important trend in modern economic relations (TNB accumulate financial resources from the most convenient and beneficial sources, transforming them into those spheres, where their implementation will be the most profitable). If previously TNBs were issuing loans, mainly on foreign trade transactions of the economic entities, now at the present stage of development they are crediting any operations of their clients. The main purpose of the article is to identify the impact of TNBs on the economic and financial sector development of the developing countries by constructing the regression models and analyzing their results. According to the stated task, there is an econometric model of the TNB impact evaluation on the development of the economy and financial sector in Poland, Brasil and Turkey, which were included to the list of "Top-20 emerging economies". The dependent variable of the regression equation, GDP per capita was chosen as an indicator of economic development of these countries. The independent variables included a share of assets of foreign banks in the country's total banking system, the share of foreign banks in their total number, correlation of the credits, given in the private sector to the GDP and ratio of deposit to GDP. The list of independent variables includes also the capitalization level of the stock market for Poland and Brazil. The study period was 21 years, from 1995 to 2015. Poland is characterized by the fact that the country's economy is the most influenced by such indicators as the share of assets of foreign banks in total banking assets of Poland, as well as the proportion of foreign banks among the total number of banks. The author points out the high level of the banking sector internationalization in Poland that relates to measures, approved by the country's government, to stabilize the state's economy and to attract foreign investors. For Brazil and Turkey, loans and deposits relative to GDP have the greatest impact on the development of their economies. In Brazil, with an increase in the volume of loans issued, there was a reduction in household incomes. So in the country, the majority of the population has the overdue loans, moreover, GDP per capita also has had a downward trend since 2011. For the Turkish economy, the increase of the given credits and deposits quantity leads to the increase of the inhabitants' incomes in the country. Besides, only for this country, the impact of TNB on the financial sector is statistically significant.

Keywords: transnational banks, economic development, financial sector, loans, deposits, foreign capital.

Formulation of the problem. In connection with the intensification of the globalization processes which are taking place in the world economy and the financial sector, the interconnection of national economies is strengthening, the role of external factors in economic development is increasing, and the financial markets are converging.

The world economy is a complex system which is formed under the influence of various factors. The main place in the world financial market among its many participants is occupied by transnational banks which can provide a wide range of needs of all participants in international economic relations. Therefore the issue of analyzing the influence of transnational banks on the economic and financial sector of the country is very important. 

Developing Countries (on the Example of Poland, Brazil, Turkey)

Analysis of recent researche and publications. The study of the activities of transnational banks, their influence on the world economy, the evaluation of the significance of TNB in the financial sphere was carried out by such scientists as M. Borovinsky, A. Kosevich, V. Kozhina, I. Otmar, A. Romashova, U. Umantseva, R. Peterson.

Previously unsettled problem constituent. The study of the influence of transnational banks on selected countries has never been conducted before. As Poland, Turkey and Brazil are among the most successful developing countries in their regions, then by examining the impact of TNBs on their economies and the financial sectors, it will be possible to project results to other countries in the respective regions.

Purpose of the article. The main purpose of the article is to identify the factors that have the greatest impact on the economic and financial development of the developing countries by constructing the regression models and analyzing their results.

Results and discussions. The transnational bank is a large universal bank that performs an intermediary role in the international movement of loan capital. It usually relies on a network of foreign branches, controls foreign exchange and credit operations on the world market with the support of the state [1].

The main purpose of transnational banks is to mobilize and redistribute funds in such a way as to maximize profits.

The foreign economic activity of TNB is a generating factor for the expansion and development of globalization processes, the economic ties of most countries in the world. The increasing importance of TNBs in the world economy is explained by the consolidation of banking and industrial capital, which is an important trend in modern economic relations. If previously TNBs were issuing loans, mainly on foreign trade transactions, now they are crediting any operations of their clients.

One of the main activities of TNBs is the acceptance of deposits. For transnational banks this operation has acquired features related to the international scope of activity. The features that distinguish TNB operations from the operations of national banks are the following: mobilization of capital, its further movement from country to country in order to obtain maximum profit, a high level of flexibility in management. TNB covers all types of savings, from the government to small investors.

TNB is also an active source for advancing scientific and technological progress as they are flexible enough to "transfuse" capital from one country to another. But based on their nature of origin TNB is trying to completely subordinate all financial flows to maximize its own benefits. That is why TNBs are also a source of severe economic crises in the world economy [2].

TNBs have certain advantages in comparison with other banks. Thus, transnational banks are less prone to economic crises because international operations dominate in their activities, which allows them to remain less dependent on the state of any country. Moreover, TNBs retain high-profit growth rates and are more resistant to fluctuations in the economy.

The existence of an extensive network of foreign units located in countries with different phases of the business cycle is of great importance to TNBs, which enables the diversification of sources of profit and less dependence on economic conditions.

TNBs are the main agents of economic expansion and play a contradictory role. On the one hand, they serve as agents of new aggressive forms of production and management organization, and also are the financial donors. Their expansion helps to increase the rate and level of economic growth of the backward countries. On the other hand, their expansion reinforces the imbalances in the economies of these countries because individual enterprises and industries, which mainly focus on foreign capital, are developing. Moreover, in developing countries, the environment is deteriorating due to the transfer of "dirty" technologies to them.

To assess the impact of TNBs on the economy and the financial sector, three developing countries, which were included in the list of "Top-20 emerging economies", were selected [3]. Those are Poland, 
Brazil and Turkey.

For Poland, a regression model was constructed using the following indicators:

- as a dependent variable, GDP per capita $(Y)$ was chosen as an indicator of economic development [4];

- as independent variables were chosen: share of assets of foreign banks in the total banking assets of Poland $\left(X_{1}\right)$; share of foreign banks among the total number of banks $\left(X_{2}\right)$; capitalization of the stock market $\left(X_{3}\right)$; loans to the private sector in relation to $\operatorname{GDP}\left(X_{4}\right)$ and the ratio of deposits to $\operatorname{GDP}\left(X_{5}\right)$. The study period was 21 years, from 1995 to 2015 [5-9].

The model can be characterized by such an indicator as $R^{2}$, the value of which is 0.93 . Other indicators of the model indicate its adequacy. In this model, all indicators are significant (except capitalization of the stock market). The final model looks like this:

$$
\mathrm{Y}=-11932.786+101.630 * \mathrm{X} 1+95.987 * \mathrm{X} 2+154.335 * \mathrm{X} 4+917.819 * \mathrm{X} 5
$$

There is a direct dependence between the share of assets of foreign banks in the total banking assets of Poland, as well as the proportion of foreign banks among the total number of banks, and GDP per capita, i.e. with an increase in the share of assets of foreign banks in total banking assets and the share of foreign banks among the total number of banks there is an increase in GDP per capita. This is due to the fact that, since the privatization of the banking sector and to date, the presence of foreign capital is very large. So, as of 2015 , the Polish banking sector is internationalized - approximately $76 \%$ of assets are controlled by foreign owners, mainly from EU countries. In general, about $95 \%$ of the banking system of Poland is made up of banks with foreign capital. In particular, the Polish government struggled to avoid the domination of the banks of the economic leader of the region - Germany. The first place was taken by Italian banks $-12.8 \%$ as of 2014 . Italy is followed by Germany, Spain, Holland [10, p. 6].

The arrival of foreign capital in the banking system of Poland was associated with privatization processes in order to stabilize the economy, as well as attracting foreign investment.

There is a direct dependence between credits, deposits and GDP per capita in Poland, i.e. with an increase in the volume of loans and deposits, there is an increase in the incomes of the population. As of 2016 interest rate on loans and deposits is 1.5\%. Poland uses the so-called "cheap money" policy, whose goal is to stimulate the economic activity of the population. There is a revival of production, which leads to an increase in the number of jobs, a reduction in unemployment, an improvement of the well-being of the population. Especially retail lending contributes to the development of the economy of Poland and any state. In this case, debt relations are a source of increasing the welfare of the population, the most important factor in the growth of consumption and production [11].

To assess the impact of TNBs activities on the Brazilian economy, a regression model was constructed using the following indicators: as a dependent variable, GDP per capita $(Y)$ was chosen as an indicator of economic development [12]; as independent variables were chosen: the share of assets of foreign banks in the country's total banking assets $\left(X_{1}\right)$; share of foreign banks among the total number of banks $\left(X_{2}\right)$; capitalization of the stock market $\left(X_{3}\right)$, loans given to the private sector in relation to $\operatorname{GDP}\left(X_{4}\right)$ and the ratio of deposits to $\operatorname{GDP}\left(X_{5}\right)$. The study period was 21 years, from 1995 to 2015[13-17].

The model can be characterized by $R^{2}$, whose value is 0.97 . Other indicators of the model indicate its adequacy. In this model insignificant were the share of assets of foreign banks in total banking assets of the country and the share of foreign banks among the total number of banks. The final model looks like this:

$$
\mathrm{Y}=-21549.412+71.423 * \mathrm{X} 3-352.349 * \mathrm{X} 4+513.626 * \mathrm{X} 5
$$



Developing Countries (on the Example of Poland, Brazil, Turkey)

There is a direct dependence between capitalization of the stock market and GDP per capita, so, as the value of securities circulating on the market increases, the incomes of the population also increase.

The stock market influences the economy because it is the main mechanism for the redistribution of capital between sectors and business entities. Brazilian securities market is among the fastest growing in Latin America. As Brazilian securities market grows, its role in the development of the country's economy is growing, as well as the growth of the economy itself.

Between credits granted to the private sector and GDP per capita an inverse relationship is observed, i.e. with an increase in the volume of loans issued, respectively, there is a reduction in household incomes. In 2016 a large part of the population, about 48\%, had overdue loans. GDP per capita also has a downward trend since 2011 , so for this period it has declined by $8.6 \%$ [12]

Direct dependence is observed between the ratio of deposits to GDP and GDP per capita. The Central Bank of Brazil, starting from 2013, constantly raises the deposit rate, which is due to the fact that the price increase in the country occurs at a faster rate than the level of inflation.

In Turkey, for more than 10 years the inflation rate and interest rates have significantly decreased. As of 2015 inflation was $7.7 \%$, which is $47.2 \%$ less than was recorded in 2000 . The interest rate decreased from $13.8 \%$ in 2008 to $7.7 \%$ in 2016 . Reducing inflation and low-interest rates help to increase the investment and revive domestic consumption. So, in 2015 the inflow of FDI was $\$ 17.55$ billion, which was almost $\$ 5$ billion more than in the previous year [18-20].

To assess the impact of TNB activities on the Turkish economy, a regression model was constructed using the following indicators: as a dependent variable, GDP per capita $(Y)$ was chosen as an indicator of economic development [21]; as independent variables were taken: the share of assets of foreign banks in the country's total banking assets (X1); share of foreign banks among the total number of banks (X2); loans to the private sector in relation to GDP (X4) and the ratio of deposits to GDP (X5). The study period was 21 years, from 1995 to 2015 [22-26].

The model can be characterized by $\mathrm{R}^{2}$, the value of which is 0.93 . Other parameters of the model indicate its correctness. In this model, the share of foreign banks among the total number of banks and capitalization of the stock market was insignificant. The final model looks like this:

$$
\mathrm{Y}=-30113,373+1237,268 * \mathrm{X} 1+280,089 * \mathrm{X} 4+433,425 * \mathrm{X} 5
$$

Analyzing the equation obtained, it can be seen that a direct relationship exists between GDP per capita and all independent variables.

Thus, as the share of assets of foreign banks in the total banking assets of Turkey increases, the growth of such indicator as GDP per capita is observed. However, it is worth noting the insignificant presence of foreign banks in the country. So, as of 2015, the share of assets of foreign banks was slightly more than $13 \%$ [22].

Between credits, deposits and GDP per capita in Turkey, there is a direct dependence, i.e. with an increase in the volume of loans and deposits, there is an increase in the incomes of the population. So, in 2015 rates on loans and deposits were approximately at the same level of $12 \%$ and $11 \%$ respectively [20].

To assess the impact of TNBs' activities on the financial sector of Poland, Brazil, Turkey, the regression models were constructed using the following indicators: as a dependent variable, the national debt was selected as a percentage of GDP $(Y)$; as independent variables were chosen: the share of assets of foreign banks in the country's total banking assets $(X 1)$; share of foreign banks among the total number of banks (X2); loans to the private sector in relation to GDP (X4) and the ratio of deposits to GDP (X5). The study period was 21 years, from 1995 to 2015.

However, such a model for Poland and Brazil can not be used, because $\mathrm{R}^{2}$ is very low for them. Turkey's model can be characterized by such $\mathrm{R}^{2}$, the value of which is 0.77 . In this model, the share of 
assets of foreign banks in total banking assets of the country and capitalization of the stock market was insignificant. The final model looks like this:

$$
\mathrm{Y}=18,065-0,773 * \mathrm{X} 2-1,240 * \mathrm{X} 4+2,322 * \mathrm{X} 5
$$

The dependence between the share of foreign banks among the total number of banks and state debt is reverse, i.e. an increase in the number of foreign banks in Turkey leads to a reduction in public debt. Foreign presence contributes to attracting additional investments in the banking sector - capitalization is increasing, efficiency is improving, competition is increasing, lending to the economy is intensifying, an effect that stimulates other investors is created, because the more people invest in the country, the more confidence and interest it causes. The financial sector and the banks that have gained confidence among Turkish population have a binding role between the owners of savings and entrepreneurs who use these savings for investment. In this way, savings contribute to investment, as well as employment, and generally contribute to economic development.

The state debt of Turkey reached its maximum value of $74.1 \%$ in 2001 . However, after this, there was a tendency to reduce the country's debt, and in 2015 it was $29 \%$, which is the norm according to the Convergence Criteria. Turkish financial sector has recovered after the crisis of 2001, and despite the global financial crisis of 2008, it continues to arouse investor interest [27].

The growth of GDP contributes to the reduction of the national debt of the country and increases the strengthening of banking activity in Turkey. The volume of loans and deposits is growing. Indicators of the ratio of deposits to GDP and the national debt of the country are falling with GDP growth. Hence, there is a direct dependence between the ratio of deposits to GDP and state debt.

Conclusions and offers. Transnational banks, being subjects of the world economy, have distributed their branches around the world; they conduct many different operations outside one country, control economic processes within individual states, as well as currency and financial ties between states.

TNBs fully meet the needs of their customers in the international market, constantly expanding the range of services of existing international banking products. They contribute to the development of credit and financial and technological ties between the banks of these countries, help to increase the rate and level of economic growth of the lagging countries.

The activity of TNBs is to accept deposits, issue loans; they are the driving force of the scientific and technical progress. TNBs have certain advantages: they are less susceptible to economic crises, have the opportunity to diversify their sources of profit and to be less dependent on economic conditions.

The article analyzes the influence of TNBs on the economy of three developing countries. Poland is characterized by the fact that the country's economy is the most influenced by such indicators as the share of assets of foreign banks in total banking assets of Poland, as well as the proportion of foreign banks among the total number of banks. The banking sector is very internationalized. The arrival of foreign capital in the banking systems of Poland was associated with the privatization processes in order to stabilize the economy, as well as attracting foreign investment. Between credits, deposits and GDP per capita in Poland, there is a direct dependence. The country uses a policy of low interest rates to stimulate economic activity of the population.

For Brazil and Turkey, loans and deposits relative to GDP have the greatest impact on the development of their economies.

In Brazil, with an increase in the volume of loans issued, there was a reduction in household incomes. So in the country, the majority of the population has the overdue loans, moreover, GDP per capita also has had a downward trend since 2011. The reverse dependence is observed between deposits and BBA per capita. The Central Bank of the country constantly raises the rate on deposits, which is explained by the fact that the price increase occurs at a faster rate than the level of inflation. 

Developing Countries (on the Example of Poland, Brazil, Turkey)

Between credits, deposits and GDP per capita in Turkey there is a direct dependence, i.e. with an increase in the volume of loans and deposits, there is an increase in the incomes of the population.

When constructing models that characterize the influence of the TNB on the financial sector, only the Turkish one turned out to be significant. As a result, it was revealed that an increase in the number of foreign banks in the country leads to a reduction in public debt. The growth of GDP contributes to the reduction of the national debt of the country and increases the strengthening of banking activity in Turkey. The volume of loans and deposits is growing. The ratio of deposits to GDP and the national debt of the country are falling with GDP growth. Hence, there is a direct dependence between the ratio of deposits to GDP and state debt.

It is promising to conduct similar studies for Ukraine. Since the country is of interest to foreign investors, in particular, the banking sector, in recent years banks with foreign capital have been gradually expanding their presence in the Ukrainian market. Among the largest international banks operating in Ukraine through the establishment of a subsidiary bank or with partial participation in the capital of domestic banks, we can mention Raiffeisenbank (Austria), Calvon Bank, SNG Bank (Netherlands), Citigroup, HVB Bank and others.

When determining the expediency of increasing the presence of foreign capital in the country's banking system, it is necessary to be guided by the strategic priorities of the country, the practical implementation of which will ensure the integrity and stability of the functioning of the national banking system. Since 2012, most foreign banks are not ready to exit Ukrainian market and close their branches. All financial institutions understand that leaving this market is economically inefficient for them.

At the present stage, the share of foreign bank capital in Ukraine has significantly decreased and reached the identical indicators of the pre-crisis period.

The future of foreign banking groups in Ukraine depends on political and economic regulation, as well as normative regulation. If the country is fully prepared for profound reforms, the transition to international standards, in the future the situation will improve.

Sovremennyy ekonomicheskiy slovar': - 6-ye izd./ pererab. i dop. - M." (INFRA-M) Rayzberg B., Lozovskiy L., Starodubtseva Y., 2011. [Electronic resource]. - Access mode: http://www.consultant.ru/document/cons_doc_LAW_ 67315/f8998da85fb12d4e8a858d364ab485dfad0863b4 / (in Russian)

Mansurova A. (2013) «Rol' transnatsional'nykh bankov v sisteme mezhdunarodnykh ekonomicheskikh otnosheniy» [Electronic resource]. - Access mode:http:iupr.ru/domains_data/files/zurnal_13_2014/Mansurova_2013.pdf (in Ukrainian)

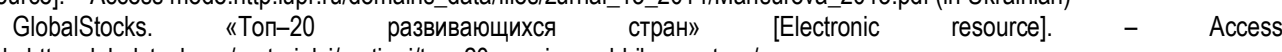
mode:http:.globalstocks.ru/materialyi/reytingi/top-20-razvivayushhihsya-stran/

The World Bank Data. Indicators. GDP per capita. Poland [Electronic resource]. - Access mode: https: data.worldbank.org/indicator/ NY.GDP.PCAP.CD?locations=PL

FRED. Economic Data. Categories .International Data .Percentage of Foreign Bank Assets Among Total Bank Assets for Poland [Electronic resource]. - Access mode: https:.fred.stlouisfed.org/series/DDOI14PLA156NWDB

Data Market. Percentage of Foreign Banks Among Total Banks. Poland [Electronic resource]. - Access mode: https:.datamarket.com/data/set/47dv/foreign-bank-assets-among-total-bank-

assets\#!ds=47dv!73c7=3f\&display=choropleth\&map=world\&classifier=natural\&numclasses $=5$

FRED. Economic Data. Categories. International Data. Stock Market Capitalization to GDP for Poland [Electronic resource]. Access mode: https:.fred.stlouisfed.org/series/DDDM01PLA156NWDB

The World Bank Data. Indicators. GDP per capita. Pland. Domestic credit to private sector (\% of GDP) [Electronic resource]. Access mode:https:.data.worldbank.org/indicator/FS.AST.PRVT.GD.ZS?end=2016\&locations=PL\&start=1995

FRED. Economic Data. Categories .International Data .Bank Deposits to GDP for Poland [Electronic resource]. - Access mode: https:.fred.stlouisfed.org/series/DDO102PLA156NWDB

NBP. Banking sector development levels (commercial and cooperative banks) in selected CEE countries and in the euro area Financial System in Poland 2001-2015 [Electronic resource]. - Access mode: http:.www.nbp.pl/en/systemfinansowy/fsd_2015.pdf; Economic Forecasts from the World's Leading Economists. Countries .Poland .Interest Rate [Electronic resource]. - Access mode:https:.www.focus-economics.com/country-indicator/poland/interest-rate

FRED. Economic Data. Categories .International Data .GDP per capita for Brazil [Electronic resource]. - Access mode: 
https:.fred.stlouisfed.org/series/PCAGDPBRA646NWDB

FRED. Economic Data. Categories. International Data .Percentage of Foreign Bank Assets Among Total Bank Assets for Brazi [Electronic resource]. - Access mode:https: fred.stlouisfed.org/series/DDOI14BRA156NWDB

DataMarket. Percentage of Foreign Banks Among Total Banks Percentage of Foreign Banks Among Total Banks/Brazil [Electronic resource]. - Access mode:https:.datamarket.com/data/set/3ypq/percentage-of-foreign-bank-assets-among-totalbank-assets-for-brazil\#!ds=3ypq\&display=line

FRED. Economic Data. Categories .International Data .Stock Market Capitalization to GDP for Brazil[Electronic resource]. Access mode:https: fred.stlouisfed.org/series/DDDM01BRA156NWDB

The World Bank Data. Indicators. Domestic credit to private sector (\% of GDP).Brazil [Electronic resource]. - Access mode:https..data.worldbank.org/indicator/FS.AST.PRVT.GD.ZS?end=2016\&locations=BRA\&start=1995

FRED. Economic Data. Categories .International Data .Bank Deposits to GDP for Brazil[Electronic resource]. - Access mode: https: fred.stlouisfed.org/series/DDOI02BRAA156NWDB

The World Bank Data. Indicators. Foreign direct investment, net inflows. Turkey [Electronic resource]. - Access mode: https..data.worldbank.org/indicator/BX.KLT.DINV.CD.WD?locations=TR

FRED. Economic Data. Categories .International Data .Inflation [Electronic resource]. - Access mode: https:.fred.stlouisfed.org/series/FPCPITOTLZGTUR:

Tradingeconomics. Turkey interest rate [Electronic resource]. - Access mode: $h$ ttps:.tradingeconomics. com/turkey/interest-rate The World Bank Data. Indicators. GDP per capita. Turkey [Electronic resource]. - Access mode:https:.data.worldbank.org/indicator/NY.GDP.PCAP.CD?locations=TR

FRED. Economic Data. Categories .International Data .Percentage of Foreign Bank Assets Among Total Bank Assets for Turkey[Electronic resource]. - Access mode: https: fred.stlouisfed.org/series/DDOI14TRA156NWDB

FRED. Economic Data. Categories. International Data .Percentage of Foreign Banks Among Total Banks for Turkey [Electronic resource]. - Access mode: https:fred.stlouisfed.org/series/DDOI13TRA156NWDB

FRED. Economic Data. Categories .International Data .Stock Market Capitalization to GDP for Turkey [Electronic resource]. Access mode: https: fred.stlouisfed.org/series/DDDM01TRA156NWDB

The World Bank Data. Indicators. Domestic credit to private sector (\% of GDP).Turkey [Electronic resource]. - Access mode:https..data. worldbank.org/indicator/FS.AST.PRVT.GD.ZS?end=2016\&locations=TR\&start=1995

FRED. Economic Data. Categories .International Data .Bank Deposits to GDP for Turkey [Electronic resource]. - Access mode: https: fred.stlouisfed.org/series/DDOI02TURA156NWDB

OECD Central Government Debt Database. Central government debt, total (\% of GDP).Turkey [Electronic resource]. - Access mode: http..stats.oecd.org/index.aspx?queryid=55\#

А. Д;: Л. Фернандес, доктор, професор Жана Моне , Гейдельберзький університет (Гейдельберг, Німеччина).

Вплив транснаціональних банків на розвиток економіки і фінансового сектора країн, що розвиваються (на прикладі Польщі, Бразилії, Туреччини)

Автор статті наголошує, що саме зовнішньоекономічна діяльність транснаціональних банків (ТНБ) в теперішній час стає ключовим фактором глобалізаційних транссформацій, оскільки вона сприяє консолідації банківського і промислового капіталу (ТНБ акумулюють фінансові ресурси з найбільш зручних і вигідних джерел, трансформуючи їх у ті сфери, де їх використання буде найбільш прибутковим). Якщо раніше діяльність ТНБ була пов'язана лише з кредитуванням зовнішньоторговельних операцій суб'єктів господарської діяльності, та на сучасному етапі розвитку вони здійснюють кредитування будь-яких операцій своїх клієнтів. Основною метою статті є вивчення впливу ТНБ на розвиток економіки і фінансового сектора країн, що розвиваються. У роботі відповідно до поставленого завдання побудовано економетричну модель оцінки впливу ТНБ на розвиток економіки і фінансового сектора Польщі, Бразилії та Туреччини, які були включені до cписку "Ton-20 економік, що розвиваються". У якості залежної змінної регресійного рівняння прийнято показник ВВП на душу населення як характеристика економічного розвитку цих країн. До складу незалежних змінних включено частку активів іноземних банків у загальних активах банківської системи країни, частку іноземних банків у загальній їх кількості, співвідношення кредитів приватному сектору до ВВП та співвідношення депозитів до ВВП. Для Польщі та Бразилії до переліку незалежних змінних додано ще й рівень капіталізації фонддового ринку цих країн. Період дослідження складав 21 рік (з 1995 р. по 2015 р.). Отримані результати засвідчили позитивний вплив на економічний розвиток Польщі частки активів іноземних банків у сукупних активах банківської системи країни, а також частки іноземних банків узагальній кількості банків. Автором відмічається високий ступінь інтернаціоналізації банківського сектору Польщі, що пов'язано з прийнятими урядом країни заходами по стабілізації економіки держави, а також залученню іноземних інвестицій. Для Бразилії та Туреччини кредити і депозити по відношенню до ВВП мають найбільший вплив на розвиток економіки. При иьому у Бразилії зі збільшенням обсягу виданих кредитів відбулося зниження доходів домогосподарств. Таким чином, в країні велика частка населення має прострочені кредити, крім того, з 2011 року ВВП на душу населення також мав тенденцію до зниження. Для економіки Туреччини збільшення обсягу наданих кредитів і депозитів сприяло збільшенню доходів населення країни. Окрім цього, лише для цієї країни влив ТНБ на фрінансовий сектор виявився статистично значимим.

Ключові слова: транснаціональні банки, економічний розвиток, фінансовий сектор, кредити, депозити, іноземний капітал. 